\title{
Sığır Kas ve Böbrek Dokularında Antibiyotik Kalıntılarının Araştırılması*
}

\author{
Semra GÜRBÜZ ${ }^{1, a, * *}$ \\ ${ }^{1}$ Gastronomi ve Mutfak Sanatları Bölümü, Mardin Artuklu Üniversitesi Turizm Fakültesi, Mardin, Türkiye \\ aORCID: 0000-0002-7099-0308
}

\begin{abstract}
Tarihi: 19.04.2020
Kabul Tarihi: 17.06.2020

Özet: Bu çalışmada sığır kas ve böbrek dokularında antibiyotik varlığının araştırıması amaçlandı. Çalışmada, Ankara'daki mezbahalarda kesimi yapılan 100 adet sığırın kas ve böbrek dokusu ile parekende satış yerlerinden alınan 100 adet sığır kas dokusu olmak üzere toplam 300 örnek test materyali olarak kullanıldı. Örnekler antibiyotik kalıntılarının tesbiti için $10^{7}$ $\mathrm{kob} / \mathrm{ml}$ Bacillus subtilis BGA spor solusyonunun ilave edildiği Üç Plak Test yöntemi kullanılarak test edildi. İncelenen 300 örneğin 5'i kas ve 2'si böbrek dokusu olmak üzere 7 (\%2.3)'sinde antibiyotik kalıntısı bulunduğu, pozitif bulunan 4 kas örneğinin birden fazla pH değerinde inhibisyon zonu oluşturduğu saptandı. Böbrek örneklerinden 4 (\%1.3)'ü şüpheli olarak değerlendirilirken, 289 (\%96.4) örnekte antibiyotik varlığı tespit edilmedi. Tüketime sunulan hayvansal dokularda antibiyotik kalıntıları bulunması önemli sağlık problemlerine neden olabileceği için hayvan yetiştiricilerinin bilinç düzeyinin artırımasına yönelik çalışmaların etkin ve devamlı yapılmasının faydalı olacağı kanaatına varıldı.
\end{abstract}

Anahtar Kelimeler: Ilaç kalıntıları, Veteriner ilaçları, Antibakteriyel ajanlar, Sığır kas dokusu, Sığır böbreği.

\section{Investigation of Antibiotic Residues in Muscle and Kidney Tissues of Cattle}

Abstract: This study aimed to investigate the presence of antibiotics in cattle muscle and kidney tissues. In the study, a total of 300 samples were used as test materials, including the muscle and kidney tissues of 100 cattle slaughtered in slaughterhouses and 100 cattle muscle tissues taken from retail stores in Ankara. Samples were tested using the Three Plate Test method in which $10^{7} \mathrm{cfu} / \mathrm{ml}$ Bacillus subtilis BGA spore solution was added to detect antibiotic residues. It was determined that $7(2.3 \%)$ of the 300 samples examined, 5 of which were muscle tissue and 2 of which were kidney tissue, had antibiotic residues, and 4 positive muscle samples formed an inhibition zone at more than one pH value. While 4 (1.3\%) of the kidney samples were considered suspicious, the presence of antibiotics was not detected in 289 (96.4\%) samples. Since the presence of antibiotic residues in animal tissues offered for consumption may cause important health problems, it is thought that it will be beneficial to carry out training aimed at increasing awareness of animal breeders effectively and continuously.

Keywords: Drug residues; Veterinary drugs, Anti-bakterial agents, Cattle muscle tissue, Cattle kidney

\section{Giriş}

Antibiyotikler, insanlarda ve hayvanlarda enfeksiyöz hastalıkların tedavisi ile hayvan yetiştiriciliğinde metafilaktik, profilaktik ve gelişmeyi destekleyici olarak düşük dozlarda yemlere ilave edilerek yaygın olarak kullanılmaktadır (ChaferPericas ve ark., 2010; Founou ve ark., 2016; Singh ve ark., 2014; Yıbar ve Soyutemiz, 2013).

Kasaplık hayvanlarda kullanılan antibiyotikler hayvansal ürünlerde farklı seviyelerde kalıntı oluşmasına neden olabilmektedir. Antibiyotik kalıntılarının; ilacın yanlış kullanımı, ilaç atım süresinin takip edilmemesi, yasa dışı kullanım, yetkisiz kişilerce bilinçsiz kullanım, ilaç kullanılan hayvana ilişkin kayıtların tutulmaması, uzun süre etkili ve salınımı yavaş olan ilaçların kullanılması, hayvanın biyolojik özellikleri vb. kaynaklı olabildiğ bildirilmektedir (Acaröz ve ark., 2016; Aydın ve Yılmaz Aksu, 2015; Bayou ve Haile, 2017; Beyene, 2016).

Antibiyotik kalıntısı bulunan gıdalar, tüketicilerde alerjik reaksiyonlar ve çeşitli toksik etkilere, mide bağırsak sistemindeki yararlı mikroorganizmaların yok olmasına neden olabildiği gibi gıda endüstrisindeki fermente ürünlerin yapımında starter kültürlerin aktivitesini olumsuz yönde etkileyerek teknolojik problemlere ve ekonomik kayıplara da neden olmaktadır (Jabbar ve Ur-Rehman, 2013; Prajwal ve ark., 2017; Sanz ve ark., 2015). Çiftlik hayvanlarında metafilaktik, profilaktik ve gelişmeyi destekleyici olarak antibiyotik kullanımından kaynaklanabilen, antibiyotiklere dirençli patojen bakteriler, gıda üretim zinciri boyunca kolaylıkla yayılabilmekte ve insanlarda enfeksiyona neden olabilmektedir (Beyene, 2016; Founou ve ark., 2016; Gürbüz ve ark., 2018). Bu durum antibiyotiklerin hastalıkların tedavisindeki etkinliğini tehdit ederek çok ciddi bir halk sağlığı problemi oluşturmaktadır (Kantiani ve ark., 2009).

Gıdalarda antibiyotik kalıntılarının taranmasına yönelik çalışmalar 1970'li yıllarda Avrupa'da mikrobiyal inhibisyon testleri kullanılarak 
başlamıştır (Vishnuraj ve ark., 2016). Antibiyotik kalıntılarının izlenmesinde kullanılan analitik metodlar tarama ve konfirmasyon testlerinden oluşmaktadır (Chafer-Pericas ve ark., 2010). Almanya Sağlık Teşkilatınca uygulanan Üç Plak Testi, Avrupa Birliği Dört Plak Testi, Antibiyotik Kalıntıları için Tarama Testi vb. mikrobiyal testler genellikle tarama seviyesinde kullanilır ve numunelerde bulunan kalıntılar tarafından, besiyerine eklenen bakterinin büyümesinin inhibisyonu prensibine dayanır (Pikkemaat, 2009; Sanz ve ark., 2015). Bu çalışmada kullanılan Üç Plak Testinin üç değişik pH ortamında uygulanarak optimal antibakteriyel etkinliğin açığa çıkmasına olanak verdiği ve testin duyarlılı̆ının, yaygın olarak kullanılmakta olan diğer testlere göre eşit düzeyde veya yüksek bulunduğu bildirilmektedir (Schramm ve ark., 1994). Yalancı pozitiflik alınabileceği bildirilmekle birlikte yalancı negatiflik alınabileceğine dair bir kaynağa rastlanılmamıştır (Zamaro ve Yabut, 1989).

$\mathrm{Bu}$ çalışmada Ankara'daki mezbahalardan alınan sığır kas ve böbrek dokuları ile parakende satış yerlerinden alınan sığır kas dokularında antibiyotik varlığının Üç Plak Testi ile araştırılması amaçlanmıştır.

\section{Materyal ve Metot}

Çalışma materyali: Bu çalışmada, Ankara'daki mezbahalarda kesilen 100 sığıra ait kas ve böbrek dokusu örnekleri ile parekende satış yerlerinden satın alınan 100 sığır kas dokusu örneği olmak üzere toplam 300 örnek kullanıldı. Kas örnekleri gluteal kasların bulunduğu bölgeden, böbrek örnekleri ise 1 adet tam böbrek olarak alındı. Toplanan örnekler konteyner ile soğuk şartlarda laboratuvara ulaştırıldı ve buzdolabında saklanarak 2 gün içerisinde test edildi.

Üç Plak Testi ile antibiyotik varlığının saptanması: Örneklerde antibiyotik varlığının saptanmasında mikrobiyolojik bir yöntem olan Üç Plak Testi uygulandı (Anonim, 1986). Üç ayrı erlenmayerde hazırlanan Standart II nutrient agar (MERCK 1.07883) üzerine \% 0.1 oranında $\mathrm{KH}_{2} \mathrm{PO}_{4}$ ilave edildi. Takiben $0.1 \mathrm{~N} \mathrm{HCl}$ ve $0.1 \mathrm{~N} \mathrm{NaOH}$ kullanılarak besiyerinin $\mathrm{pH}^{\prime} \mathrm{s}$ ( $6.0,7.2$ ve $8.0^{\prime} \mathrm{e}$ ayarlandı. Besiyeri $121{ }^{\circ} \mathrm{C}^{\prime}$ de 15 dakika otoklav edildikten sonra $50{ }^{\circ} \mathrm{C}^{\prime}$ ye soğutulan besiyerinin 500 $\mathrm{ml}$ 'sine $0.5 \mathrm{ml}$ olacak şekilde Bacillus subtilis BGA suşunun $10^{7} \mathrm{kob} / \mathrm{ml}$ spor içeren solüsyonundan (MERCK 1.10649) eklendi. Besiyerlerinden pH'sı 7.2 olana ayrica konsantrasyonu $50 \mu \mathrm{g} / \mathrm{ml}$ olan trimethoprim (SIGMA T 7883) solüsyonundan $0.5 \mathrm{ml}$ ilave edildi.

Kas ve böbrek doku örneklerinin her birinden 6 adet, $8 \mathrm{~mm}$ çapında, $2 \mathrm{~mm}$ kalınlığında silindir şeklinde test örnekleri hazırlandı. Hazırlanan kas ve böbrek doku örnekleri her petriye altı adet olmak üzere, besiyerlerinin üzerine konuldu ve $30^{\circ} \mathrm{C}^{\prime}$ de 18 24 saat inkube edildikten sonra sonuçlar değerlendirildi. Besiyerlerinin çalışmasını kontrol etmek için $\mathrm{pH}^{\prime} \mathrm{sI} 6.0$ olan besi yerine $0.01 \mathrm{IU}$ penisilin $\mathrm{G}$, pH'sı 7.2 olan besiyerine $0.5 \mu \mathrm{g}$ sulfadimidin ve $\mathrm{pH}^{\prime} \mathrm{s}$ 8.0 olan besi yerine $0.5 \mu \mathrm{g}$ streptomisin (Mast Diagnostica) içeren kontrol diskleri ve antibiyotik içermeyen doku örnekleri konuldu. Aynı gün kullanılmayan besiyerleri $4^{\circ} \mathrm{C}^{\prime}$ de muhafaza edilerek 2 gün içerisinde kullanıldı. Kontrol disklerinin $30{ }^{\circ} \mathrm{C}$ 'deki etüvde $18-24$ saat sonunda $5-10 \mathrm{~mm}$ arasında zon vermesi ve bilinen negatif kontrollerin zon vermemesi besiyerlerinin çalıştığı şeklinde değerlendirildi. Örneklerden 2 mm'den geniş zon verenler pozitif, 1-2 mm arasında zon verenler ise şüpheli kabul edildi (Anonim, 1986).

\section{Bulgular}

$\mathrm{Bu}$ çalışma kapsamnda mezbahadan alınan örneklerde; aynı sığıra ait 1 kas ve 1 böbrek dokusu örneğinin $\mathrm{pH}$ 7.2' de, 1 böbrek dokusu örneğinin $\mathrm{pH}$ 8.0 'de antibiyotik varlığı yönünden pozitif; 3 böbrek dokusu örneğinin $\mathrm{pH} 6.0$ ve $7.2^{\prime}$ de, 1 böbrek dokusu örneğinin ise; sadece $\mathrm{pH}$ 6.0'da şüpheli sonuç verdiği tespit edildi (Tablo 1, 2).

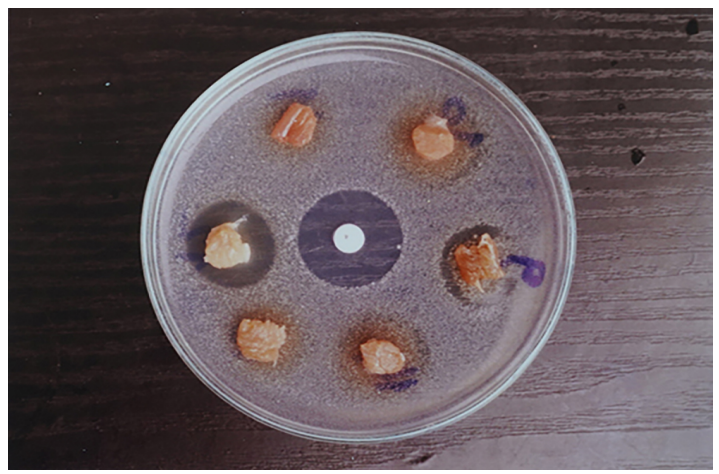

Şekil 1. P4 numaralı kas dokusu örneğinin $\mathrm{pH} 6.0^{\prime}$ daki görünümü.

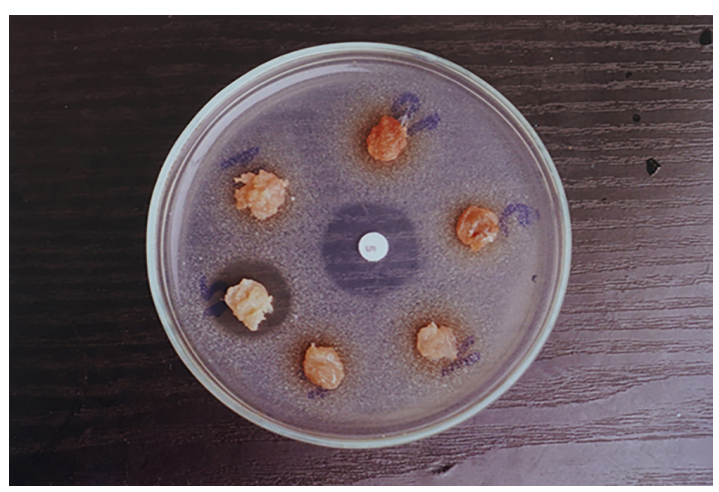

Şekil 2. P4 nolu kas dokusu örneğinin $\mathrm{pH} 7.2^{\prime}$ deki görünümü. 


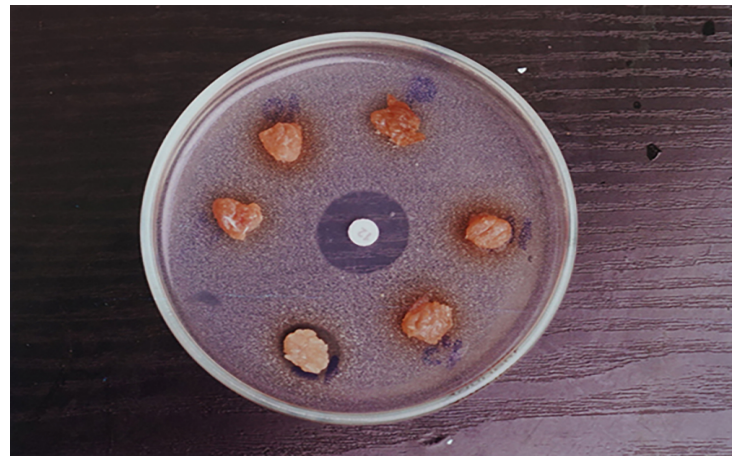

Şekil 3. P4 numaralı kas dokusu örneğinin $\mathrm{pH}$ 8.0 'deki görünümü.

Parekende satış yerlerinden alınan kas örneklerinden; 3'ü $\mathrm{pH} 6.0$ ve 7.2' de, $1^{\prime} \mathrm{i}$ ise $\mathrm{pH}$ 6.0, 7.2 ve $8.0^{\prime}$ de pozitif sonuç verdi (Tablo 1,2 , Şekil 1 , 2, 3).

İncelenen toplam 300 örneğin 5'i kas ve 2'si böbrek dokusu örneği olmak üzere 7 (\%2.3)'sinde antibiyotik kalıntısı bulunduğu saptandı. Böbrek örneklerinden $\quad 4 \quad(\% 1.3)^{\prime}$ ü şüpheli olarak değerlendirildilirken, $289 \quad$ (\%96.3) örnekte antibiyotik varlığı tespit edilmedi. (Tablo 1). Kontrol diskleri 7-8 mm'lik inhibisyon zonu verirken negatif kontroller inhibisyon zonu göstermedi.

\section{Tartışma ve Sonuç}

Türkiye'de ve diğer ülkelerde yapılan çalışmalarda, kasaplık hayvan dokularında antibiyotik kalıntısı varlığının tespit edildiği bildirilmektedir (Aydemir ve ark., 2019; Bahmani ve ark., 2019; Gruber ve ark., 1988; Oruç ve ark., 2007; Sanz ve ark., 2015; Wahab ve ark., 2011; Yüksel, 2001; Zamora ve Yabut, 1989).

Türkiye'de yapılan çalışmalarda; Yüksel (2001) tarafından; disk diffüzyon ve farklı bakterilerin kullanıldığı üç plak yöntemi kullanılarak yapılan çalışmada, Ankara piyasasından temin edilen 50 adet sığır böbreğinin \%14'ünde oksitetrasiklin kalıntılarının saptandığı, Oruç ve ark. (2007) tarafından ELISA yöntemi ile yapılan çalışmada

Tablo 1. Incelenen kas ve böbrek dokusu örneklerinde antibiyotik kalıntısı varlığı.

\begin{tabular}{llllll}
\hline Örneklem Yeri & Örnek & Örnek & Pozitif & Şüpheli & Negatif \\
& Tipi & Sayısı & $\mathbf{n ~ ( \% ) ~}$ & $\mathbf{n}(\%)$ & $\mathbf{n}(\%)$ \\
\hline Mezbaha & Böbrek & 100 & $2(2)$ & $4(4)$ & $94(94)$ \\
& Kas & 100 & $1(1)$ & - & $99(99)$ \\
Parekende Satış Yerleri & Kas & 100 & $4(4)$ & - & $96(96)$ \\
\hline Toplam & & $\mathbf{3 0 0}$ & $\mathbf{7 ( 2 . 3 )}$ & $\mathbf{4}$ & $\mathbf{2 8 9}(\mathbf{9 6 . 3 )}$ \\
\hline
\end{tabular}

Tablo 2. Incelenen örneklerde farklı pH değerlerinde alınan sonuçlar.

\begin{tabular}{|c|c|c|c|c|c|c|c|c|}
\hline Örneklem Yeri & \multirow[t]{3}{*}{ Örnek No } & \multirow[t]{3}{*}{ Örnek Tipi } & \multicolumn{3}{|c|}{ Pozitif } & \multicolumn{3}{|c|}{ Şüpheli } \\
\hline & & & $\mathrm{pH}$ & & & $\mathrm{pH}$ & & \\
\hline & & & 6.0 & 7.2 & 8.0 & 6.0 & 7.2 & 8.0 \\
\hline \multirow[t]{3}{*}{ Mezbaha } & $\mathrm{P} 1 *$ & Kas & & $x$ & & & & \\
\hline & $\mathrm{P} 2 *$ & Böbrek & & $x$ & & & & \\
\hline & P3 & Böbrek & & & $x$ & & & \\
\hline Parakende Satış & P4 & Kas & $x$ & $x$ & $x$ & & & \\
\hline \multirow[t]{3}{*}{ Yeri } & P5 & Kas & $x$ & $x$ & & & & \\
\hline & P6 & Kas & $x$ & $x$ & & & & \\
\hline & $\mathrm{P} 7$ & Kas & $x$ & $x$ & & & & \\
\hline \multirow[t]{4}{*}{ Mezbaha } & \$̧1 & Böbrek & & & & $x$ & & \\
\hline & \$̧2 & Böbrek & & & & $x$ & $x$ & \\
\hline & \$̧3 & Böbrek & & & & $x$ & $x$ & \\
\hline & \$̧4 & Böbrek & & & & $x$ & $x$ & \\
\hline
\end{tabular}

P: Pozitif bulunan örnekleri göstermektedir Ş: Şüpheli bulunan örnekleri göstermektedir. *Aynı karkasa ait kas ve böbrek dokusudur.

Bursa ve civarından toplanan 63 sığır eti örneğinde streptomisin ve 60 sığır eti örneğinde sulfametazin kalıntılarının sırası ile \%6 ve \%1.5 oranında tespit edildiği, bununla birlikte tespit edilen kalıntı düzeylerinin, yasal olarak izin verilen maksimum kalıntı limitlerinin altında bulunduğu bildirilmektedir. Aydemir ve ark. (2019) tarafından Şanlıurfa'da kasaplarda satışa sunulan 20 sığır ve 20 koyun olmak üzere toplam 40 kıyma örneğinde Premi ${ }^{\circ}$ Test ile yapılan çalışmada, sığır kıyma 
örneklerinde \%50, koyun kıyma örneklerinde ise $\% 60$ pozitif sonuç tespit edildiği belirtilmektedir.

$\mathrm{Bu}$ araştırmada bulunan \%2.3 oranındaki pozitif sonuç; hayvanlara çeşitli hastalıklar nedeniyle tedavi amaçlı antibiyotik uygulanmasını takiben antibiyotiğin yasal arınma süresinden önce hayvanların kesime sevk edilmesi, hayvanla ilgili tedavi kayıtlarının düzgün tutulmaması, kesim öncesi süreçte hayvan sahibinin değişmesi ve önerilen dozun üzerinde antibiyotik kullanımı kaynaklı olabilir. Bu araştırma ile ülkemizde yapılan diğer araştırma sonuçları arasındaki farkılık kullanılan örnek sayıları, metot farklılıkları ve örneklerin toplandığı alanlardaki yetiştirme pratiğinden kaynaklanabilir.

Ette antibiyotik kalıntıların varlığını araştırmak için farklı ülkelerde yapılan çalışmaların sonuçları değişkenlik göstermektedir. Sanz ve ark. (2015) İspanya'da 1302 örneğin \%7.1'inde, Wahab ve ark. (2011) Sudan'da 300 örneğin \%17.3'ünde, Bahmani ve ark. (2019) Iran'da 360 örneğin \%21.3'ünde antibiyotik kalıntısı varlığının tespit edildiğini bildirilmektedir. Bulunan sonuçlar sunulan çalışmadaki \%2.3'lük pozitiflik oranından çok yüksektir.

$\mathrm{Bu}$ çalışmada aynı sığıra ait kas ve böbrek örneğinde $\% 1$, sadece böbrekte ise $\% 0.5$ oranında pozitif sonuç bulunmuştur. Üç Plak Testi kullanarak, Avusturya'da 9212 kas ve böbrek dokusu örneğinde yapılan bir çalışmada örneklerin \%2.9'unun antibiyotik kalıntı varlığı yönünden pozitif bulunduğu, kas ve böbreğin her ikisinde birden \%1.01, sadece böbrekte ise \%1.9 oranında pozitif sonuç bulunduğu bildirilmektedir (Gruber ve ark., 1988). Bulunan sonuç bu çalışma sonuçları ile benzerdir.

Filipinler'de 50 adet domuz kası örneği ile Üç Plak Testi kullanılarak yapılan bir diğer çalışmada; $\% 12$ oranında pozitif, \%8 oranında ise şüpheli sonuç tespit edildiği, pozitif bulunan 6 örneğin $5^{\prime}$ inin $\mathrm{pH}$ 6.0 ve $7.2^{\prime}$ de ve 1 tanesinin de her üç $\mathrm{pH}^{\prime} \mathrm{da}$ da pozitif reaksiyon verdiğini bildirilmektedir (Zamora ve Yabut, 1989). Araştırmacıların bulduğu sonuç ile benzer şekilde bu çalışmada parekende satış yerlerinden alınan kas örneklerinin 4'ü pozitif bulunmuş ve pozitif kas örneklerinden $3^{\prime}$ ünün $\mathrm{pH}$ 6.0 ve $7.2^{\prime}$ de 1 kas örneğinin ise $\mathrm{pH} 6.0,7.2$ ve 8.0 'de pozitif olduğu tespit edilmiştir (Tablo 2, Şekil $1,2,3)$. Üç Plak Testinde; tetrasiklin, oksitetrasiklin, klortetrasiklin, penisilin, basitrasin, nalidinik asit, flavomisin, kloramfenikol vb. antibiyotiklerin $\mathrm{pH}$ $6.0^{\prime} \mathrm{da}$, sulfonamidlerin trimethoprim ilave edilen $\mathrm{pH} 7.2^{\prime}$ de aminoglikozid ve makrolidlerin ise $\mathrm{pH}^{\prime} \mathrm{s}$ 8.0 olan besiyerinde optimum antibakteriyel etki gösterdiği belirtilmektedir (Anonim, 1986). Bu çalışmada sadece $\mathrm{pH} 7.2^{\prime}$ de pozitif sonuç veren aynı hayvana ait kas ve böbrek örneğinde sulfonamid grubu, pH 8.0'de pozitif reaksiyon veren böbrek örneğinde ise aminoglikozid ve makrolid grubu bir antibiyotik kalıntısı bulunabilir. Birden fazla $\mathrm{pH}$ değerinde pozitif sonuç veren kas örneklerinde birden fazla antibiyotik kalıntısı bulunabileceği gibi, bir $\mathrm{pH}^{\prime} \mathrm{da}$ optimum aktivite gösterirken diğer $\mathrm{pH}^{\prime}$ larda da aktivite gösterebilen bir antibiyotik kalıntısının da bulunabileceği düşünülmektedir.

Üç Plak Testinde aynı antibiyotik için farklı pH değerine sahip besiyerlerinde inhibisyon zonlarında 4-6 mm değişikliğin oluştuğu bildirilmektedir (Schramm ve ark., 1994). Benzer şekilde bu çalışmada, her üç $\mathrm{pH}^{\prime}$ da da pozitif reaksiyon veren kas örneğinin, $\mathrm{pH}$ 6.0, 7.2 ve 8.0'de sırası ile $6 \mathrm{~mm}, 5$ $\mathrm{mm}$ ve $2 \mathrm{~mm}$ inhibisyon zonu verdiği tespit edilmiştir.

Sonuç olarak; antibiyotik kalıntıları insanlarda çeşitli toksik etkilere ve teknolojide üretim hatalarına, sıklıkla ve uygun olmayan şekilde antibiyotik kullanılması patojen bakterilerde antibiyotik direnci gelişmesine neden olabilmektedir. Tüm bunlar gıda güvenliği ve tüketici sağığı açısından risk oluşturmaktadır. Bu nedenle gıda güvenliği yetkilileri ve sahada çalışan veteriner hekimler tarafından, antibiyotiklerin kullanım koşulları ile yanlış ve yasal olmayan kullanım kaynaklı tehlike ve riskler konusunda hayvan yetiştiricilerinin bilgilendirilmeleri önemli görülmektedir.

\section{Kaynaklar}

Acaröz U, Arslan Acaröz D, Gürler Z, 2016: Gıdalarda Antibiyotik Kalıntılarının Saptanması için Enzim İmmunoassay Geliştirilmesi. Kocatepe Vet J, 9(2), 122-126.

Anonim, 1986: Allgemeine Verwaltungsvorschrift über die Durchführung der amtlichen Untersuchungen nach dem Fleishhygienegesetz (VwVFIHG) VOM 11.Dezember 1986, (Banz. Nr.238a vom 23. Dezember 1986).

Aydemir MA, Kılıç Altun S, Durmaz H, 2019: Detection of Antibiotic Drug Residues with Premi ${ }^{\oplus}$ Test in Sold Meats in Şanlıurfa Province. Harran Univ Vet Fak Derg, 8 (2), 128-131.

Aydın A, Yılmaz Aksu F, 2015: Gıdalarda Veteriner illaç Kalıntıları. Turkiye Klinikleri J Food Hyg TechnolSpecial Topics, 1(1), 1-9.

Bahmani K, Shahbazi Y, Nikousefat Z, 2019: Monitoring and risk assessment of tetracycline residues in foods of animal origin. Food Sci Biotechnol, 26;29(3):441448

Bayou K, Haile N, 2017: Review on Antibiotic Residues in Food of Animal Origin: Economic and Public Health Impacts. Appl J Hygiene, 6(1), 01-08.

Beyene T, 2016: Veterinary Drug Residues in Food-animal Products: Its Risk Factors and Potential Effects on Public Health. J Veterinar Sci Technol, 7, 285. 
Chafer-Pericas C, Maquieira A, Puchades R, 2010: Fast screening methods to detect antibiotic residues in food samples. Trends Anal Chem, 29(9), 1038-1049.

Founou LL, Founou RC, Essack SY, 2016: Antibiotic Resistance in the Food Chain: A Developing CountryPerspective. Front Microbiol, 7, 1881.

Gruber VH, Hinterdorfer F, Jarc H, 1988: Erfahrungen mit der Verwendung einer $\mathrm{B}$. licheniformis-Platte zum besseren Sulfonamid nach weis im biologishen Hemmstoff test. Wien Tierattl Mschr, 76, 157-160.

Gürbüz S, Keskin O, Gürbilek SE, Tel OY, Akın Yigin A, Demirci M, 2018: Presence of Staphylococcus aureus, staphylococcal enterotoxins and antimicrobial resistance in traditionally produced raw milk cheeses. J Food Saf Food Qual, 69, 171176.

Jabbar A, Ur-Rehman S, 2013: Microbiological Evaluation of Antibiotic Residues in Meat, Milk and Eggs. J Microbiol Biotechnol Food Sci, 2(5), 2349-2354.

Kantiani L, Marinella Farré M, Barceló D, Barceló D, 2009: Analytical methodologies for the detection of $\beta$ lactam antibiotics in milk and feed samples. Trends Anal Chem, 28(6), 729-744.

Oruç HH, Cengiz M, Bağdaş D, Uzunoğlu i, 2007: Sığır Etlerinde Streptomisin ve Sulfametazin (Sulfadimidin) Kalıntıları. Uludag Univ J Fac Vet Med, 26(1-2), 17-20.

Pikkemaat MG, 2009: Microbial screening methods for detection of antibiotic residues in slaughter animals. Anal Bioanal Chem, 395, 893-905.

Prajwal S, Vasudevan VN, Sathu T, Irshad A, Nayankumar SR, Pame K, 2017: Antibiotic residues in food animals: Causes and health effects. J Pharm Innov, 6(12), 01-04.

Sanz D, Razquin P, Condón S, Juan T, Herraiz B, Mata L, 2015: Incidence of Antimicrobial Residues in Meat
Using a Broad Spectrum Screening Strategy. Eur J Nutr Food Saf, 5(3), 156-165.

Schramm G, Ellerbroek L, Weise E, Reuter G, 1994: Mikrobiologischer Hemmstoffnachweis in fleisch 2 Experimenteller vergleich des Neuen Niederlandischen Nierentestsund der USamerikanischen STOP-und Cast-Test mit dem Dreiplattentest. Fleischw, 74, 649-652.

Singh S, Shukla S, Tandia N, Kumar N, Paliwal R, 2014: Antibiotic Residues: A Global Challenge. Pharma Sci Monit, 5(3), 184-197.

Vishnuraj MR, Kandeepan G., Rao KH, Chand S, Kumbhar V, 2016: Occurrence, public health hazards and detection methods of antibiotic residues in foods of animal origin: A comprehensive review. Cogent Food Agric, 2, 1, 1235458.

Wahab Alla MB, Mohamed TE, Abdelgadir AE, 2011: Detection of Antibiotics Residues in Beef in Ghnawa Slauterhouse, Khartoum State, Sudan. $U$ of K. J. Vet. Med. \& Anim. Prod, 2 (1), 71-88.

Yıbar A, Soyutemiz E, 2013: Antibiotics Use in FoodProducing Animals and Possible Residual Risk. Atatürk Üniversitesi Vet. Bil. Derg, 8(1), 97-104.

Yüksek N, 2001 Etlerde Antibiyotik Kalıntılarının Aranması Üzerinde Çalışmalar. J Fac Vet Med, 20, 85-90.

Zamaro BM, Yabut JMP, 1989: Detection of antibacterial residues in pork using Hermsstoff test. Phil J Vet Med, 26, 3-6.

*Bu makale "Sığır Etlerinde Antibakteriyel İnhibitör Maddelerin Aranması" başlıklı doktora tez çalışmasından türetilmiştir.

**Yazışma adresi: Semra GÜRBÜZ

Mardin Artuklu Üniversitesi, Turizm Fakültesi, Gastronomi ve Mutfak Sanatları Bölümü, Mardin, Türkiye.

e-mail: semragurbuz@gmail.com 